\title{
Electrochemical Analysis of Protein Nitrotyrosine and Dityrosine in the Alzheimer Brain Indicates Region-Specific Accumulation
}

\author{
Kenneth Hensley, ${ }^{1}$ Michael L. Maidt, ${ }^{1}$ Zhenqiang Yu, ${ }^{1}$ Hong Sang, ${ }^{1}$ William R. Markesbery, ${ }^{2}$ and \\ Robert A. Floyd ${ }^{1}$ \\ ${ }^{1}$ Free Radical Biology and Aging Research Program, Oklahoma Medical Research Foundation, Oklahoma City, Oklahoma \\ 73104, and 2Department of Neurology and Anatomy and Sanders Brown Center on Aging, University of Kentucky, \\ Lexington, Kentucky 40528
}

HPLC with electrochemical array detection (HPLC-ECD) was used to quantify 3,3'-dityrosine (diTyr) and 3-nitrotyrosine (3$\mathrm{NO}_{2}-\mathrm{Tyr}$ ) in four regions of the human brain that are differentially affected in Alzheimer's disease (AD). DiTyr and 3- $\mathrm{NO}_{2}-\mathrm{Tyr}$ levels were elevated consistently in the hippocampus and neocortical regions of the $A D$ brain and in ventricular cerebrospinal fluid (VF), reaching quantities five- to eightfold greater than mean

The Alzheimer's disease (AD) brain exhibits region-specific patterns of amyloid plaque deposition, neurofibrillary tangle (NFT) accumulation, and neuron death. The limbic system and association areas of the neocortex show the most pronounced histopathological alterations in $\mathrm{AD}$, whereas cortical somatosensory and cerebellar neurons are relatively spared (Pearson et al., 1985; Henderson and Finch, 1989; Braak and Braak, 1994). Recent models of AD attempt to link disease progression with an inflammatory component combined with increased oxidative stress (Rogers et al., 1996). Classical hallmarks of inflammation such as edema and neutrophil infiltration are not acknowledged characteristics of the AD brain, although numerous correlates of inflammation are present. Acute-phase reactants such as C-reactive protein, major histocompatibility complex glycoproteins, complement, monocyte chemoattractants, interleukin-1, and interleukin- 6 are elevated in AD brain in spatial association with neuritic plaques (Griffin et al., 1989, 1995; McGeer et al., 1989; Bauer et al., 1991; Strauss et al., 1992; Carpenter et al., 1993; Wood et al., 1993; Iwamoto et al., 1994; Mrak et al., 1995; Pereira et al., 1996; Rogers et al., 1996; Sheng et al., 1996). Reactive microglia, functionally similar to monocytes, are increased in the AD brain and concentrate near senile plaques (McGeer et al., 1987; Haga et al., 1989; Itagaki et al., 1989; Carpenter et al., 1993; MacKenzie et al., 1995).

Enhanced oxidative stress in the AD brain is manifested by increases in protein carbonyl content and lipid and DNA oxidation products and by inactivation of sensitive enzymes (Oliver et al., 1987; C. Smith et al., 1991, 1992; Mecocci et al., 1993; Balazs and Leon, 1994; Chen et al., 1994; Hensley et al., 1995; Lovell et al., 1995; M. Smith et al., 1996; Butterfield et al., 1997; Lyras et al., 1997; Sayre et al., 1997). Correlation between oxidative and

\footnotetext{
Received June 4, 1998; revised July 20, 1998; accepted July 30, 1998.

This work was supported in part by Grants from National Institutes of Health (NS35747 and PO1-AG05119), Oklahoma Center for the Advancement of Science and Technology (OCAST H97-067), and the Abercrombie Foundation.

Correspondence should be addressed to Dr. Kenneth Hensley at the above address.

Copyright (C) 1998 Society for Neuroscience $\quad 0270-6474 / 98 / 188126-07 \$ 05.00 / 0$
}

concentrations in brain and VF of cognitively normal subjects. Uric acid, a proposed peroxynitrite scavenger, was decreased globally in the $A D$ brain and VF. The results suggest that $A D$ pathogenesis may involve the activation of oxidant-producing inflammatory enzyme systems, including nitric oxide synthase.

Key words: HPLC; nitrotyrosine; dityrosine; Alzheimer's disease; protein oxidation; inflammation inflammatory biomarkers has not been achieved in the AD brain, although the activation of an inflammatory response might, in large part, explain AD brain oxidation. For instance, activated microglia release superoxide $\left(\mathrm{O}_{2} \cdot^{-}\right)$and hydrogen peroxide $\left(\mathrm{H}_{2} \mathrm{O}_{2}\right)$ (Colton et al., 1994), whereas astrocytes and microglia stimulated with appropriate cytokines or $\beta$-amyloid peptides $(\mathrm{A} \beta)$ express inducible nitric oxide synthase (iNOS) and generate nitric oxide-derived species, including peroxynitrite $\left(\mathrm{ONOO}^{-}\right)$ (Beckman et al., 1994; Goodwin et al., 1995; Li et al., 1996; Hensley et al., 1997).

In the present study HPLC with electrochemical array detection (HPLC-ECD) was used to quantify discrete tyrosine oxidation products expected to form during an inflammatory response. Tyrosine (Tyr), 3-nitrotyrosine (3- $\mathrm{NO}_{2}$-Tyr), and 3,3'-dityrosine (diTyr) were determined simultaneously in the protein digests of brain specimens obtained from AD and neuropathologically normal subjects. The presence of $3-\mathrm{NO}_{2}-\mathrm{Tyr}$ is thought to indicate NOS-derived peroxynitrite (Hensley et al., 1997; M. Smith et al., 1997; Yi et al., 1997), whereas diTyr formation and protein cross-linking are associated with peroxidase activity and neutrophil or macrophage activation (Heinecke et al., 1993; SalmanTabcheh et al., 1993; Savenkova et al., 1994; Domigan et al., 1995; Marquez and Dunford, 1995; Eiserich et al., 1996, 1998; Jacob et al., 1996; Malencik and Anderson, 1996; Malencik et al., 1996; Michon et al., 1997). DiTyr and 3-NO - -Tyr were elevated markedly in the AD brain, especially in the hippocampus. Moreover, uric acid, a proposed endogenous antioxidant and $\mathrm{ONOO}^{-}$scavenger, was decreased in $\mathrm{AD}$ in a manner consistent with the increases of 3- $\mathrm{NO}_{2}$-Tyr and diTyr. These findings indicate a relationship between the inflammatory state and oxidative damage in the AD brain.

\section{MATERIALS AND METHODS}

CNS tissue. Specimens were obtained at postmortem from five cognitively normal subjects and $11 \mathrm{AD}$ patients who met National Institute of Neurological and Communicative Disorders and Stroke-Alzheimer's Disease and Related Disorders Association (NINCDS-ADRDA) Work Group Criteria for AD (McKhann et al., 1984; Henderson and Finch, 
1989). All AD subjects met accepted criteria for the histopathological diagnosis of AD (Mirra et al., 1993; National Institute on Aging, 1997). Normal subjects were members of a volunteer group who underwent annual neuropsychological testing. Normal individuals had no history of dementia, neurological disease, or systemic diseases likely to affect the brain. The mean age \pm SD of normal subjects was $78 \pm 6$ years (three male, two female) and of AD subjects was $78 \pm 8$ years (seven male, four female). The mean postmortem interval $\pm \mathrm{SD}$ was $3.0 \pm 1.6 \mathrm{hr}$ for AD and $2.6 \pm 0.5 \mathrm{hr}$ for normal subjects. The mean duration $\pm \mathrm{SD}$ of clinically defined $\mathrm{AD}$ was $10 \pm 6$ years (uncertain in 2 of 11 cases). Specimens were frozen in liquid $\mathrm{N}_{2}$ and stored at $-80^{\circ} \mathrm{C}$ until processing for HPLC-ECD. Tissue from four brain regions was collected from each individual: hippocampus and parahippocampal gyrus (HIP), inferior parietal lobule (IPL), superior and middle temporal gyri (SMTG), and cerebellum (CBL). Ventricular cerebrospinal fluid (VF) was removed from the lateral ventricles before the brain was removed from the cranial vault. VF was centrifuged at $1000 \times g$ for $10 \mathrm{~min}$ and frozen at $-80^{\circ} \mathrm{C}$.

Tissue preparation before HPLC-ECD analysis. Brain specimens (300$500 \mathrm{mg}$ ) were homogenized with a Dounce-type homogenizer in $10 \mathrm{~mm}$ sodium acetate $(\mathrm{NaOAc}), \mathrm{pH} 6.5$, and protein concentration was determined by the Lowry method (Lowry et al., 1951). VF was not homogenized. A protease digestion strategy was used to liberate tyrosine residues, as described previously (Hensley et al., 1997). Samples (homogenate or VF) were mixed with freshly prepared solutions of $S$. griseus protease (Pronase) to yield $5.0 \mathrm{mg} / \mathrm{ml}$ brain protein and $1 \mathrm{mg} / \mathrm{ml}$ Pronase in a volume of $0.25 \mathrm{ml}$. Similar samples were prepared without Pronase for the purpose of determining unbound (free) concentrations of analytes. Pronase-treated samples were incubated for $18 \mathrm{hr}$ at $50^{\circ} \mathrm{C}$, after which they were treated with a $10 \%$ volume of $60 \%$ trichloroacetic acid (TCA) and centrifuged for $10 \mathrm{~min}$ at $14,000 \times g$ at $4^{\circ} \mathrm{C}$. Samples that were not treated with Pronase were subjected immediately to TCA precipitation and centrifugation. Supernatants were removed and passed through a $0.4 \mu \mathrm{m}$ polyvinylidene difluoride membrane. Filtrates were frozen at $-80^{\circ} \mathrm{C}$ until analysis.

HPLC-ECD analytical protocols. Routine HPLC-ECD was performed on an ESA (Chelmsford, MA) model 5600 CoulArray instrument equipped with eight detector cells operating in the oxidative mode at specified potentials, as previously described (channel/potential $=1,180$ $\mathrm{mV} ; 2,240 \mathrm{mV} ; 3,350 \mathrm{mV} ; 4,600 \mathrm{mV} ; 5,700 \mathrm{mV} ; 6,750 \mathrm{mV} ; 7,830 \mathrm{mV}$; $8,900 \mathrm{mV}$ ) (Hensley et al., 1997). The working electrode was porous carbon, whereas the reference and counter electrodes were palladium wire. Analyte separation was conducted on a TOSOHAAS (Montgomeryville, PA) reverse-phase ODS $80-\mathrm{T}_{\mathrm{M}} \mathrm{C}$ - 18 analytical column $(4.6 \mathrm{~mm}$ inner diameter $\times 25 \mathrm{~cm} ; 5 \mu \mathrm{m}$ particle size). A two-component gradient elution system was used, with component A of the mobile phase being 50 mM NaOAC, $50 \mathrm{~mm}$ citric acid, and $0 \%$ methanol, pH 3.1, and component B being similar to A except with $20 \%$ methanol $(\mathrm{MeOH})$. A gradient elution profile was used as follows: $0-20 \mathrm{~min}, 0 \% \mathrm{MeOH} ; 20-30$ min, linear ramp to $10 \% \mathrm{MeOH} ; 30-40 \mathrm{~min}$, isocratic $10 \% \mathrm{MeOH}$; 40-50 min, linear ramp to $15 \% \mathrm{MeOH} ; 50-60 \mathrm{~min}$, isocratic $15 \%$ $\mathrm{MeOH}$; $60-70 \mathrm{~min}$, linear ramp to $20 \% \mathrm{MeOH}$; $70-90 \mathrm{~min}$, isocratic $20 \% \mathrm{MeOH}$. All standards except dityrosine were obtained from Sigma (St. Louis, MO). An automated injection protocol was used wherein each sample was included as part of a three-injection series. Injection one consisted of a mixture of standards, injection two was the actual sample to be analyzed $(60 \mu \mathrm{l})$, and injection three was the standard mixture combined with (spiked into) the sample. Components of the standard mixture were adjusted as necessary to approximate mean regional concentrations in tissue preparations. Peak assignment and quantitation were performed by an individual blind to sample identity (Hensley et al., 1997). Specific spike-recovery and stability experiments were performed to confirm that tyrosine derivatives were recovered quantitatively from brain tissue after protease treatment and that artifactual oxidation, nitration, or chlorination did not occur during TCA precipitation and subsequent manipulations.

HPLC-ECD confirmatory protocols. To validate further the assignment of HPLC peaks, we chromatographed select samples on a 12 channel $\mathrm{ECD}$, using an ion-pairing mobile phase designed to induce retention time shifts among closely eluting analytes. Cell potentials were specified as follows (channel/potential): 1, $200 \mathrm{mV} ; 2,300 \mathrm{mV} ; 3,400 \mathrm{mV} ; 4,525$ $\mathrm{mV} ; 5,600 \mathrm{mV} ; 6,625 \mathrm{mV} ; 7,650 \mathrm{mV} ; 8,675 \mathrm{mV} ; 9,700 \mathrm{mV} ; 10,750 \mathrm{mV}$; $11,825 \mathrm{mV} ; 12,900 \mathrm{mV}$. Component $\mathrm{A}$ of the two-component mobile phase was $58 \mathrm{~mm}$ lithium phosphate, $0 \%$ methanol, and $3 \mathrm{mg} / 1$ lithium

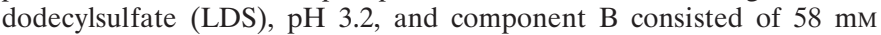
$\mathrm{Li}_{3} \mathrm{PO}_{4}, 20 \%$ methanol, and $3 \mathrm{mg} / 1 \mathrm{LDS}, \mathrm{pH} 3.2$. The gradient profile began with a 15 min isocratic elution (100\%), followed by a linear ramp to $20 \%$ methanol $(100 \%$ B) at 80 min run time. Under these conditions the 3-NO $-\mathrm{NO}_{2}$-Tyr eluted at $73 \mathrm{~min}$, whereas diTyr eluted at $86 \mathrm{~min}$. As a final test for authenticity of the $3-\mathrm{NO}_{2}$-Tyr peak, samples were treated with $10 \mathrm{~mm}$ sodium hydrosulfite to reduce $3-\mathrm{NO}_{2}$-Tyr to 3-aminotyrosine (3- $\mathrm{NH}_{2}-\mathrm{Tyr}$; Hensley et al., 1997). Although 3- $\mathrm{NH}_{2}-\mathrm{Tyr}$ elutes near the solvent front under most chromatographic conditions (Hensley et al., 1997), this analyte is shifted to a convenient retention time, using the LDS gradient $(40 \mathrm{~min})$, and oxidizes at a characteristically low potential $(150 \mathrm{mV})$.

Dityrosine synthesis and characterization. 3,3'-Dityrosine was synthesized from tyrosine and $\mathrm{H}_{2} \mathrm{O}_{2}$, using horseradish peroxidase as a catalyst according to described methods (Malencik et al., 1996). Purity and identity were verified by HPLC and by gas chromatography-mass spectrometry after derivatization with propanol and heptafluorobutyric anhydride (Heinecke et al., 1993).

Nitrite and nitrate assays. Nitrite $\left(\mathrm{NO}_{2}-\right)$ was assayed by the Griess diazotization reaction (Green et al., 1982). Nitrate $\left(\mathrm{NO}_{3}-\right)$ was assayed by the same method after treatment with nitrate reductase and NADPH, as described (Gilliam et al., 1993).

Data analysis. Tyrosine derivatives were expressed as a ratio to Tyr; uric acid was expressed as a micromolar concentration in defined and constant sample volumes. Concentration variations were assessed by two-way ANOVA, using disease state and brain region as the primary and secondary factors. Student's $t$ tests were used post hoc to determine individual $p$ values and the significance of correlations. A $p$ value $<0.05$ was considered significant.

\section{RESULTS}

\section{Validation of sample preparation}

The Pronase digestion scheme used in this study quantitatively liberates tyrosine from albumin with $\sim 5 \%$ excess tyrosine released via autohydrolysis of the protease (Hensley et al., 1997; Shigenaga et al., 1997). Pronase digestion combined with HPLCECD analysis has measured successfully the $3-\mathrm{NO}_{2}$-Tyr and $3,4-D O P A$ in glial cells treated with interleukin-1 $\beta$ (Hensley et al., 1997) and in zymosan-treated macrophages (Shigenaga et al., 1997). Proteolytic digestion eliminated the need for organic extraction and delipidation steps that would be necessary if an acid hydrolysis of proteins were attempted and avoided the charring of homogenates during acid hydrolysis.

Tyrosine, diTyr, and 3- $\mathrm{NO}_{2}-\mathrm{Tyr}$ were stable at $50^{\circ} \mathrm{C}$ in $10 \mathrm{~mm}$ $\mathrm{NaOAc}, \mathrm{pH}$ 6.5, for at least $18 \mathrm{hr}$. $\mathrm{NO}_{2}-$ and $\mathrm{NO}_{3}-(50 \mu \mathrm{M}$ each $)$ could be incubated with tyrosine $(100 \mu \mathrm{M})$ and $6 \%$ TCA for $18 \mathrm{hr}$ at $50^{\circ} \mathrm{C}$ or at room temperature for $5 \mathrm{~d}$ with $<0.01 \%$ yield of $3-\mathrm{NO}_{2}$-Tyr. DiTyr and 3-NO - -Tyr spikes were recovered quantitatively from tissue preparations incubated under protein digestion conditions. Therefore, artifacts arising from nitration, chlorination, and cross-linking of tyrosine during sample preparation were concluded not to be a concern. Tyrosine concentrations in protein digests did not vary significantly between normal and AD groups in any tissue that was studied.

\section{$\mathrm{NO}_{2}-$ and $\mathrm{NO}_{3}-$ analyses}

Mean $\mathrm{NO}_{2}-$ concentration was decreased and mean $\mathrm{NO}_{3}-$ concentration was increased in $\mathrm{VF}$ from $\mathrm{AD}$ subjects relative to normal subjects, although statistical significance was achieved only with respect to $\mathrm{NO}_{2}-\left[\right.$ mean $\pm \mathrm{SEM}\left[\mathrm{NO}_{2}-\right]=2.65 \pm 0.37$ $\mu \mathrm{M}$ (normal) versus $1.74 \pm 0.20 \mu \mathrm{M}(\mathrm{AD}), p<0.05$; mean $\pm \mathrm{SEM}$ $\left[\mathrm{NO}_{3}-\right]=2.60 \pm 0.66 \mu \mathrm{M}$ (normal) versus $3.95 \pm 0.67 \mu \mathrm{M}(\mathrm{AD})$, not significant (NS)]. The sum of $\left[\mathrm{NO}_{3}-\right]+\left[\mathrm{NO}_{2}-\right]$ did not differ between $\mathrm{AD}$ and normal groups $[5.12 \pm 0.48 \mu \mathrm{M}$ (normal) versus $5.68 \pm 0.62 \mu \mathrm{M}(\mathrm{AD})]$. Because of these trends the $\left[\mathrm{NO}_{3}-\right] /\left[\mathrm{NO}_{2}-\right]$ ratio tended to increase in $\mathrm{AD}[1.33 \pm 0.59$ (normal) versus $2.69 \pm 0.55(\mathrm{AD}), \mathrm{NS}] . \mathrm{NO}_{2}-$ and $\mathrm{NO}_{3}-$ levels in tissue homogenates were below the detection limits of the Griess assay $(1 \mu \mathrm{M})$. 
Figure 1. HPLC-ECD chromatogram of a protein digest from an AD brain (SMTG region) illustrating the resolution of peaks assigned to tyrosine (Tyr), 3,3' dityrosine (diTyr), and 3-nitrotyrosine (3- $\left.\mathrm{NO}_{2}-\mathrm{Ty} r ; \mathrm{A}\right) . \mathrm{B}, \mathrm{C}$, Expansion of chromatogram in $A$ to illustrate the resolution of dityrosine and nitrotyrosine peaks.

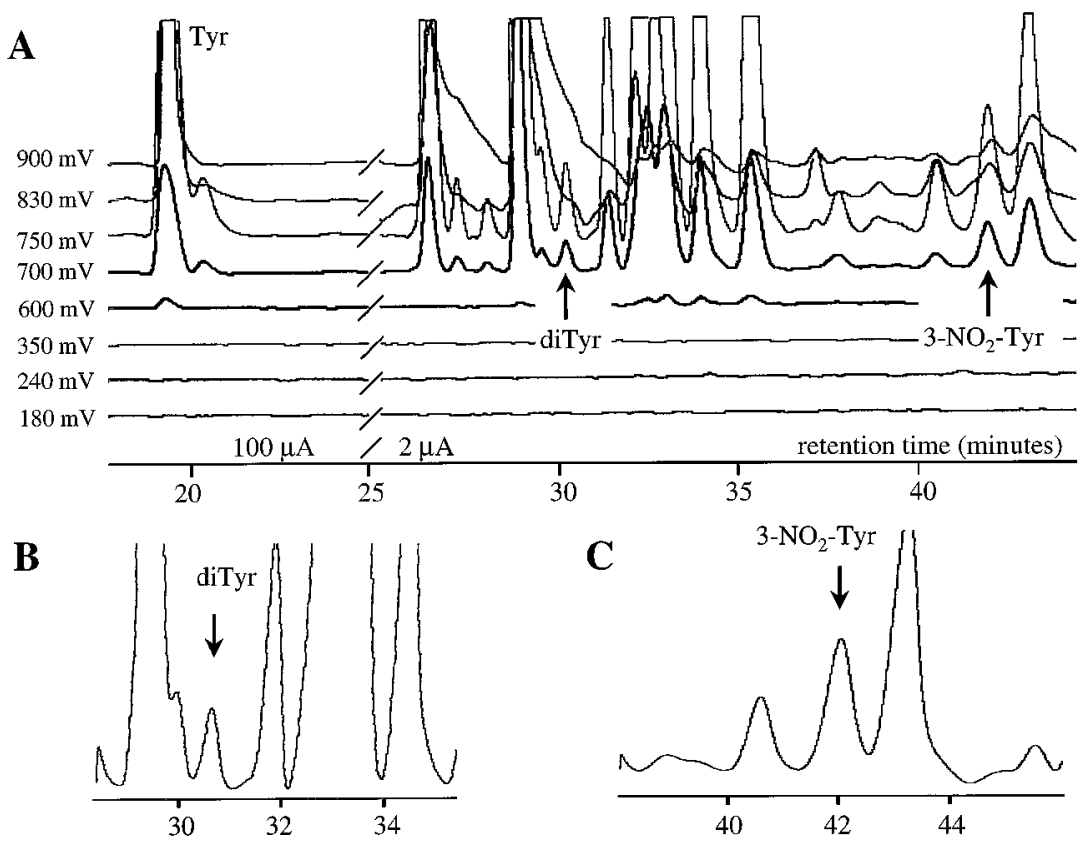

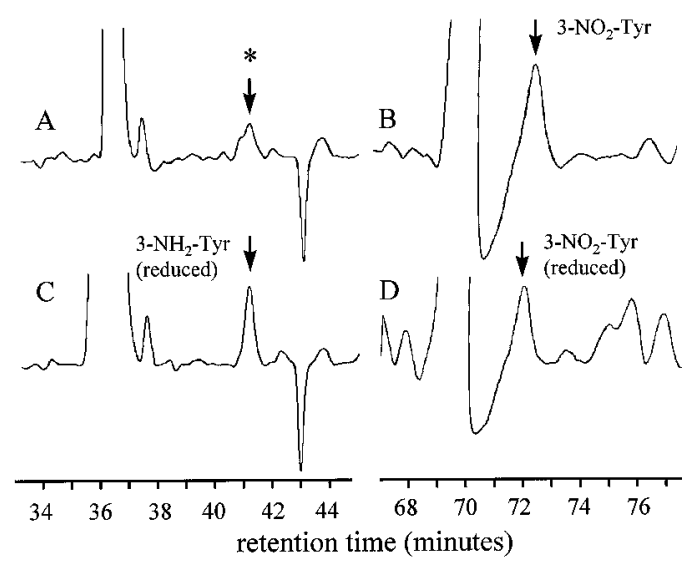

Figure 2. HPLC-ECD chromatogram of a protein digest from AD brain (SMTG region) chromatographed by using the same column as the sample shown in Figure 1, with the inclusion of LDS in the mobile phase. $A$, Original sample (full scale $=25 \mu \mathrm{A}$ current) showing ECD response at $200 \mathrm{mV}$ cell potential (channel 1). The peak marked in $A$ (asterisk) coeluted near 3- $\mathrm{NH}_{2}-\mathrm{Tyr}$ but differed markedly with respect to oxidation potential (see Results). B, Original sample at $700 \mathrm{mV}$ cell potential (channel 9) illustrating the peak assigned to $3-\mathrm{NO}_{2}$-Tyr. $C, D$, Regions of the chromatogram shown in $A$ and $B$, respectively, after treatment of the sample with hydrosulfite to partially reduce the $3-\mathrm{NO}_{2}-\mathrm{Tyr}$ to $3-\mathrm{NH}_{2}-\mathrm{Tyr}$ (labeled).

\section{3-Nitrotyrosine and 3,3'-dityrosine in brain}

Figure 1 illustrates the resolution of tyrosine derivatives in a typical HPLC-ECD chromatogram of an AD brain protein digest (SMTG region). Figure 2 illustrates $3-\mathrm{NO}_{2}-\mathrm{Tyr}$ and hydrosulfitereduced $3-\mathrm{NH}_{2}-\mathrm{Tyr}$ peaks identified in a sample prepared from the same SMTG tissue, chromatographed by using the LDS mobile phase described in Materials and Methods. DiTyr and $3-\mathrm{NO}_{2}-\mathrm{Tyr}$ coeluted with authentic standards on both gradients, with appropriate voltammetric characteristics. Furthermore, the $3-\mathrm{NO}_{2}$-Tyr peak was partially reduced to the amino derivative with hydrosulfite $[\sim 30 \%$ conversion; it should be noted that
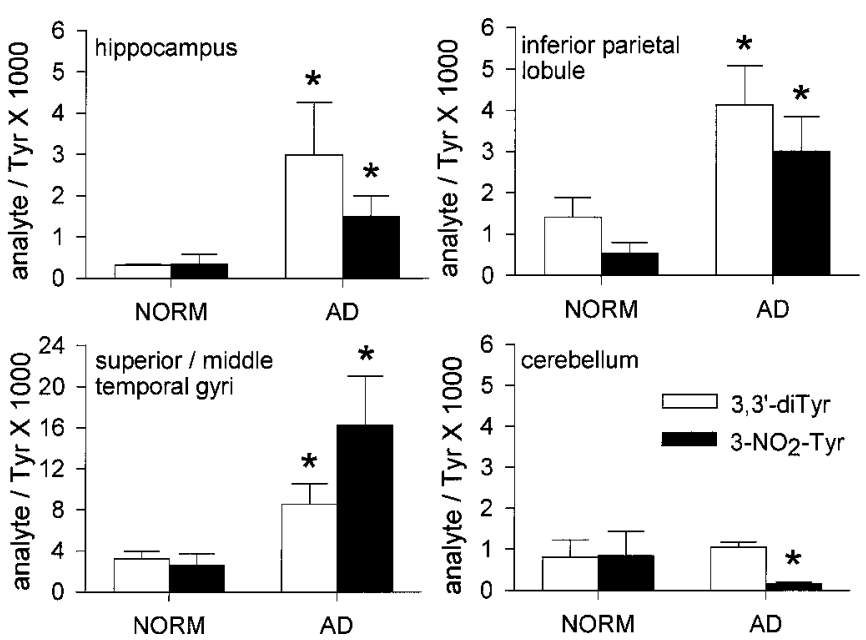

Figure 3. Quantitation of tyrosine oxidation products in various regions of the AD and normal human brains. Error bars indicate SEM; ${ }^{*} p<0.05$.

complete hydrosulfite reduction of dilute $3-\mathrm{NO}_{2}-\mathrm{Tyr}$ is a practical impossibility owing to kinetic issues and reversibility of the reaction (Hensley et al., 1997)]. 3- $\mathrm{NH}_{2}$-Tyr was not found in samples that were not treated with hydrosulfite, although small amounts of a closely eluting peak were observed that oxidized at markedly higher oxidation potential than authentic 3- $\mathrm{NH}_{2}-\mathrm{Tyr}(\sim 300 \mathrm{mV}$; electrochemical response dominant on channel 2; Fig. 2).

Both 3-NO $-\mathrm{NO}_{2}$-Tyr and diTyr were elevated significantly in AD hippocampus and cortical regions, although neither was elevated in the cerebellum (Fig. 3). 3- $\mathrm{NO}_{2}-\mathrm{Tyr}$ and diTyr concentrations covaried across brain regions $(r=0.58$ if regressed point-bypoint, $r=0.96$ by regression of mean regional values; $p<0.01$ in either case; Fig. 4). The relative difference between subject groups is most striking in the HIP region, where diTyr content increased almost fivefold and $3-\mathrm{NO}_{2}-\mathrm{Tyr}$ content increased almost eightfold in AD (see Fig. 3). Interestingly, the absolute concentrations of diTyr and $3-\mathrm{NO}_{2}$-Tyr were five- to 10 -fold 


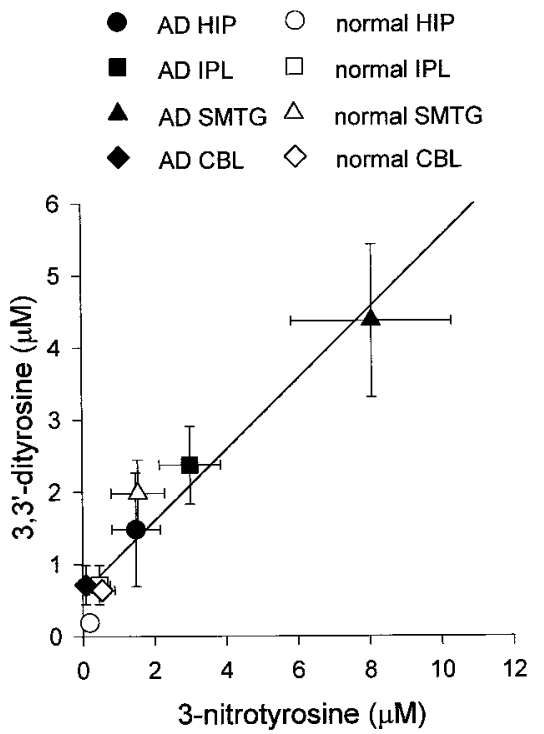

Figure 4. Correlation between dityrosine and nitrotyrosine within protein digests from normal and AD brains.

greater in SMTG than in HIP, IPL, or CBL regardless of disease state (Figs. 3, 4). Nonetheless, the relative differences in analyte levels between AD and normal SMTG were less pronounced (two- to fivefold) than corresponding HIP and IPL perturbations (Figs. 3, 4). The trends illustrated in Figures 2 and 3 were reproduced if data were expressed as absolute concentrations of analyte in protein digest or as a ratio to milligrams of protein digested. Analysis of free analytes before protease treatment indicated a negligible contribution of unbound analytes to the levels measured in the digests. The subtraction of unbound analytes resulted in 10-20\% decrease in analyte/Tyr ratios in all cases, with no alteration of statistically significant groupings, as shown in Figure 1. Additionally, 3- $\mathrm{NO}_{2}$-Tyr and diTyr were not observed if Pronase was incubated in the absence of brain protein.

\section{Tyrosine derivatives in VF}

VF contained 0.01-0.5 $\mu \mathrm{M}$ free diTyr and 3- $\mathrm{NO}_{2}-\mathrm{Tyr}$, and these values increased only two- to fivefold with protease digestion. Free diTyr content increased 3.7-fold in AD VF relative to normal VF and increased twofold in protein digests (Fig. 5). $3-\mathrm{NO}_{2}$-Tyr content increased in both free and protein digest fractions (2.3- and 1.4-fold, respectively), although this increase was not statistically significant (Fig. 5). Protein concentration within VF was similar between AD and normal groups $[0.47 \pm$ $0.15 \mathrm{mg} / \mathrm{ml}$ (normal) versus $0.41 \pm 0.03 \mathrm{mg} / \mathrm{ml}(\mathrm{AD})]$.

\section{Uric acid analysis}

Uric acid concentrations were highly variable. Nonetheless, mean values were decreased $40-50 \%$ in AD brain specimens relative to normal specimens (Fig. 6). Uric acid levels also were decreased in VF from AD subjects (Fig. 6). Although region-specific variations in uric acid were not observed, AD was found to be a significant factor in brain uric acid content ( $p<0.05$ by ANOVA). Additionally, an inverse correlation was observed between VF $\left[\mathrm{NO}_{3}-\right] /\left[\mathrm{NO}_{2}-\right]$ ratio and uric acid/protein ratio $(r=0.52 ; n=$ $16 ; p<0.05)$.

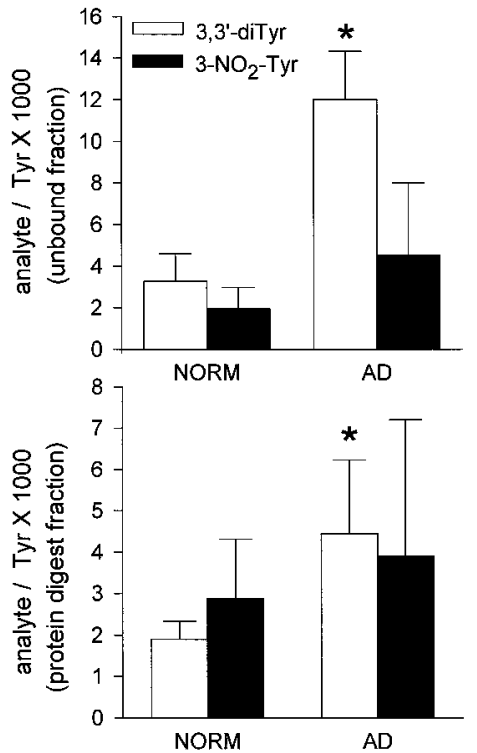

Figure 5. Dityrosine and nitrotyrosine concentrations in VF from normal and $\mathrm{AD}$ subjects. Error bars indicate SEM; ${ }^{*} p<0.05$.
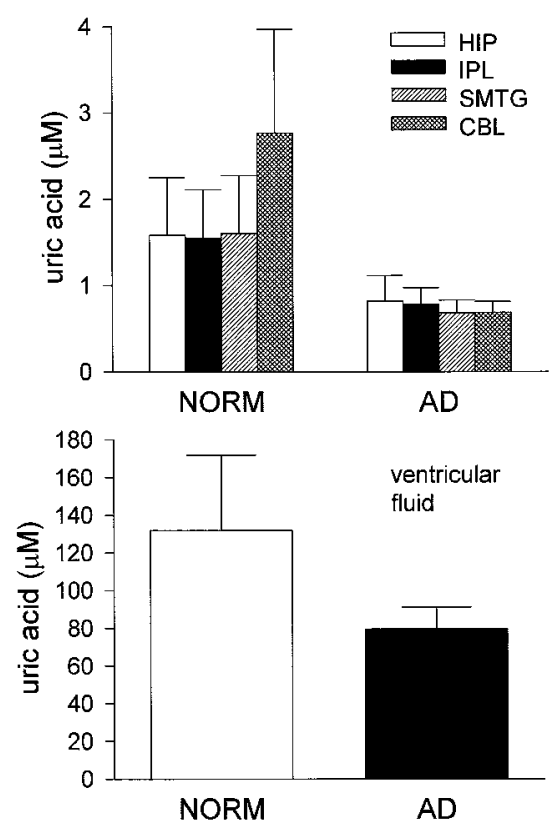

Figure 6. Uric acid content of VF and brain tissue from normal and AD subjects. Error bars indicate SEM. Uric acid concentration was depressed significantly in AD brain ( $p<0.05$ by ANOVA).

\section{DISCUSSION}

HPLC-ECD analysis of the AD brain indicates disease-related patterns of protein diTyr and $3-\mathrm{NO}_{2}-\mathrm{Tyr}$ accumulation and uric acid loss. The hippocampus, the most severely affected region of the AD brain among those presently investigated (Pearson et al., 1985; Price et al., 1991; Braak and Braak, 1994), showed the greatest relative alterations in diTyr and $3-\mathrm{NO}_{2}-\mathrm{Ty}$. Neocortical regions that also are affected in $\mathrm{AD}$ exhibited lesser relative changes in these analytes. The cerebellum, which virtually is unmarred by the landmark histopathological correlates of AD (senile plaques and neurofibrillary tangles), is unaffected by protein nitration and cross-linking. 
Several previous studies used HPLC-ECD to measure $3-\mathrm{NO}_{2}$ Tyr in brain of experimental animals and normal humans (Schulz et al., 1995; Maruyama et al., 1996). However, a recent communication by Kaur and colleagues warns that 3- $\mathrm{NO}_{2}-\mathrm{Tyr}$ determination by reverse-phase HPLC is subject to artifacts arising from an unidentified coeluting species with electrochemical similarity to $3-\mathrm{NO}_{2}-\mathrm{Tyr}$ but that differs from $3-\mathrm{NO}_{2}-\mathrm{Tyr}$ in spectroscopic characteristics (Kaur et al., 1998). The chromatographic conditions described by Kaur and colleagues used an isocratic mobile phase with high methanol content $(10 \%)$ and flow rate $(1 \mathrm{ml} / \mathrm{min})$ such that authentic $3-\mathrm{NO}_{2}$-Tyr standards eluted with a retention time of $\sim 10 \mathrm{~min}$, as did several other tested compounds, including kynurenine (Kaur et al., 1998). The chromatographic protocol described in our study was sufficient to resolve 3- $\mathrm{NO}_{2}$-Tyr from all other electrochemically active compounds we have tested, including kynurenine (retention time $\sim 79$ min under LDS-free conditions). Even using low methanol $(0 \%)$ and a slow flow rate $(0.6 \mathrm{ml} / \mathrm{min})$, we find numerous electrochemically active compounds elute within the first 15 min of the chromatographic run, with prominent peaks being poorly resolved. It is most likely that the unidentified peak described by Kaur and colleagues (1998) consists of many coeluting substances.

The current study is the first to quantify $3-\mathrm{NO}_{2}-\mathrm{Tyr}$ and to detect or quantify diTyr in the AD brain. 3- $\mathrm{NO}_{2}$-Tyr has been detected previously by immunochemical means in AD cortex, where it is associated with NFT-bearing neurons (Good et al., 1996; M. Smith et al., 1997; Su et al., 1997). HPLC-ECD and immunochemical techniques yield complementary data. Whereas immunochemical staining suggests cellular localization of analytes, the disadvantage is that specific analytes are not resolved and determined quantitatively. Interestingly, Maruyama and colleagues report an HPLC-ECD analysis of free $3-\mathrm{NO}_{2}-\mathrm{Tyr}$ in normal human brains wherein they observe threefold greater levels of 3- $\mathrm{NO}_{2}-\mathrm{Tyr}$ in cerebrum than cerebellum (Maruyama et al., 1996). The yield of 3- $\mathrm{NO}_{2}-\mathrm{Tyr}$ reported by Maruyama and colleagues in cerebrum: $\left(\left[3-\mathrm{NO}_{2}-\mathrm{Tyr}\right] /[\mathrm{Tyr}]=1.62 \times 10^{-3}\right)$, closely approximates the quantities we observe, as does the finding that cerebellum is relatively immune to protein nitration. Previous analyses of $\mathrm{NO}_{2}-$ and $\mathrm{NO}_{3}-$, two other putative indices of NO generation, have been contradictory. Kuiper and colleagues (1994) report decreased $\mathrm{NO}_{3}-$ and unchanged $\mathrm{NO}_{2}-$ in AD CSF, whereas Navarro and colleagues (1996) and Milstien and colleagues (1994) independently report no alteration in CSF $\mathrm{NO}_{2}-$ plus $\mathrm{NO}_{3}-. \mathrm{NO}_{3}-$ rather than $\mathrm{NO}_{2}-$ is thought to be the major breakdown product of $\mathrm{ONOO}^{-}$so that the ratio $\left[\mathrm{NO}_{3}-\right]$ / $\left[\mathrm{NO}_{2}-\right]$ may be a marker for $\mathrm{ONOO}^{-}$generation rather than either analyte considered independently (Pfeiffer et al., 1997). In the present study a strong trend was seen for increased VF $\left[\mathrm{NO}_{3}-\right] /\left[\mathrm{NO}_{2}-\right]$ ratio in $\mathrm{AD}$, which correlated inversely with uric acid levels and which paralleled a trend toward increased $3-\mathrm{NO}_{2}-$ Tyr content.

Tyrosine dimerization as well as nitration can be affected by ONOO $^{-}$(MacMillan-Crow et al., 1998), so the same oxidant could be responsible for the accumulation of both $3-\mathrm{NO}_{2}-\mathrm{Tyr}$ and diTyr. Alternatively, efficient synthesis of diTyr results from exposure to peroxidase enzymes. DiTyr standards used in this study were synthesized in $50 \%$ yield by the treatment of tyrosine with $\mathrm{H}_{2} \mathrm{O}_{2}$ and horseradish peroxidase (Malencik et al., 1996), although myeloperoxidase catalyzes the same reaction (Marquez and Dunford, 1995; Jacob et al., 1996). Conceivably, the induction of NOS in the AD brain could correlate with the expression or recruitment of various peroxidases. Cyclooxygenase-2 (COX-
2), a membrane-localized peroxidase involved in arachidonic acid metabolism and often expressed simultaneously with iNOS during inflammation, is expressed in AD brain (Lukiw and Bazan, 1997). It is possible that COX isoforms may be capable of diTyr synthesis, although this hypothesis has not been investigated systematically.

The decrease in uric acid levels in $\mathrm{AD}$ may be related to increased tyrosine nitration in certain brain regions. Uric acid efficiently scavenges $\mathrm{ONOO}^{-}$in vitro (Whiteman and Halliwell, 1996; our unpublished observations) and inhibits tyrosine nitration in cultured neurons challenged with $\mathrm{A} \beta$, iron salts, or $\cdot \mathrm{NO}$ generators (Mattson et al., 1997; Keller et al., 1998). Similarly, 1-100 $\mu \mathrm{M}$ concentrations of uric acid protect cultured neurons from iron and $\mathrm{A} \beta$-induced apoptosis (Mattson et al., 1997). We estimate endogenous brain uric acid concentration to be $10-50$ $\mu \mathrm{M}$ (after correction for dilution that occurs during the processing of tissue), within the apparent neuroprotective dose for this substance (Mattson et al., 1997). It is therefore possible that the uric acid decline in AD brain reflects, or possibly contributes to, AD-related neurodegeneration. One previous study reports decreased uric acid in AD CSF (Tohgi et al., 1993), whereas another reports increased uric acid in AD CSF (Degrell and Niklasson, 1988). Measurements of serum uric acid in AD are similarly contradictory (Maesaka et al., 1993; Ahlskog et al., 1995). Interestingly, uric acid reportedly protects rodents against motor dysfunction and tyrosine nitration in the experimental allergic encephalomyelitis model of multiple sclerosis (Hooper et al., 1997), suggesting that clinical symptoms of specific neurological disorders might respond to alterations in this compound.

Clearly, further research is needed to elucidate the chemistries involved in protein oxidation in the aging human brain, particularly with respect to determining which types of oxidative stress are most involved in the pathogenesis of AD. The present study suggests that oxidizing agents generated by inflammationassociated enzyme systems may be a significant contributor to protein oxidation within the AD brain. The degree to which this type of oxidative stress is involved in other neurodegenerative conditions remains to be determined.

\section{REFERENCES}

Ahlskog JE, Uitti RJ, Low PA, Tyce GM, Nickander KK, Peterson RC, Kokmen E (1995) No evidence for systemic oxidant stress in Parkinson's or Alzheimer's disease. Mov Disord 10:566-573.

Balazs L, Leon M (1994) Evidence of an oxidative challenge in the Alzheimer's brain. Neurochem Res 19:1131-1137.

Bauer J, Strauss S, Schreiter-Gasser U, Ganter U, Schlegel P, Witt I, Volk $\mathrm{B}$, Berger M (1991) Interleukin 6 and $\alpha$-2-macroglobulin indicate an acute-phase state in Alzheimer's disease cortices. FEBS Lett 285:111-114.

Beckman JS, Chen J, Ischiropoulos H, Crow JP (1994) Oxidative chemistry of peroxynitrite. Methods Enzymol 233:229-240.

Braak H, Braak E (1994) Pathology of Alzheimer's disease. In: Neurodegenerative diseases (Calne DB, ed), pp 585-613. Philadelphia: Saunders.

Butterfield DA, Hensley K, Cole P, Subramaniam R, Aksenov M, Aksenova M, Bummer PM, Haley BE, Carney JM (1997) Oxidatively induced structural alteration of glutamine synthetase assessed by analysis of spin label incorporation kinetics: relevance to Alzheimer's disease. J Neurochem 68:2451-2457.

Carpenter AF, Carpenter PW, Markesbery WR (1993) Morphometric analysis of microglia in Alzheimer's disease. J Neuropathol Exp Neurol 52:601-608.

Chen L, Richardson JS, Caldwell JE, Ang LC (1994) Regional brain activity of free radical defense enzymes in autopsy samples from patients with Alzheimer's disease and from nondemented controls. Int J Neurosci 75:83-90.

Colton CA, Snell J, Chernyshev O, Gilbert DL (1994) Induction of 
superoxide anion and nitric oxide in cultured microglia. Ann N Y Acad Sci 738:54-63.

Degrell I, Niklasson F (1988) Purine metabolites in the CSF in presenile dementia of Alzheimer type, and in multiinfarct dementia. Arch Gerontol Geriatr 7:173-178.

Domigan NM, Charlton TS, Duncan MW, Winterbourn CC, Kettle AJ (1995) Chlorination of tyrosyl residues in peptides by myeloperoxidase and human neutrophils. J Biol Chem 270:16542-16548.

Eiserich JP, Cross CE, Jones AD, Halliwell B, van der Vliet A (1996) Formation of nitrating and chlorinating species by reaction of nitrite with hypochlorous acid. A novel mechanism for nitric oxide-mediated protein modification. J Biol Chem 271:19199-19208.

Eiserich JP, Hristova M, Cross CE, Freeman BA, Halliwell B, van der Vliet A (1998) Formation of nitric oxide-derived inflammatory oxidants by myeloperoxidase in neutrophils. Nature 391:393-397.

Gilliam MB, Sherman MP, Griscavage JM, Ignarro LJ (1993) A spectrophotometric assay for nitrate using NADPH oxidation by Aspergillus nitrate reductase. Anal Biochem 212:359-365.

Good PF, Werner P, Hsu A, Olanow CW, Perl DP (1996) Evidence of neuronal oxidative damage in Alzheimer's disease. Am J Pathol 149:21-28.

Goodwin JL, Uemura E, Cunnick JE (1995) Microglial release of nitric oxide by the synergistic action of $\beta$-amyloid and IFN- $\gamma$. Brain Res 692:207-214

Green LC, Wagner DA, Gogowski J, Skipper PL, Wishnok JS, Tannenbaum SR (1982) Analysis of nitrate, nitrite, and ${ }^{15} \mathrm{~N}$ nitrate in biological fluids. Anal Biochem 126:131-138.

Griffin WST, Stanley LC, Ling C (1989) Brain interleukin-1 and S-100 immunoreactivity are elevated in Down syndrome and Alzheimer disease. Proc Natl Acad Sci USA 86:7611-7615.

Griffin WST, Sheng JG, Roberts GW, Mrak RE (1995) Interleukin-1 expression in different plague types in Alzheimer's disease: significance in plaque evolution. J Neuropathol Exp Neurol 54:276-281.

Haga S, Akai K, Ishi T (1989) Demonstration of microglial cells in and around senile plagues in the Alzheimer brain. An immunohistochemical study using a novel monoclonal antibody. Acta Neuropathol (Berl) 77:569-575.

Heinecke JW, Li W, Daehnke III HL, Goldstein JA (1993) Dityrosine, a specific marker of oxidation, is synthesized by the myeloperoxidasehydrogen peroxide system of human neutrophils and macrophages. J Biol Chem 268:4069-4077.

Henderson VR, Finch CE (1989) The neurobiology of Alzheimer's disease. J Neurosurg 70:335-353.

Hensley K, Hall N, Subramaniam R, Cole P, Harris M, Aksenov M, Aksenova M, Gabbitta SP, Wu JF, Carney JM, Lovell M, Markesbery WR, Butterfield DA (1995) Brain regional correspondence between Alzheimer's disease histopathology and biomarkers of protein oxidation. J Neurochem 65:2146-2156.

Hensley K, Maidt ML, Pye QN, Stewart CA, Wack M, Tabatabaie T, Floyd RA (1997) Quantitation of protein-bound 3-nitrotyrosine and 3,4-dihydroxyphenylalanine by high-performance liquid chromatography with electrochemical array detection. Anal Biochem 251:187-195.

Hooper DC, Bagasra O, Marini JC, Zborek A, Ohnishi ST, Kean R, Champion JM, Sarker AB, Bobroski L, Farber JL, Akaike T, Maeda H, Koprowski H (1997) Prevention of experimental allergic encephalomyelitis by targeting nitric oxide and peroxynitrite: implications for the treatment of multiple sclerosis. Proc Natl Acad Sci USA 94:2528-2533.

Itagaki S, McGeer PL, Akiyama H, Zhu S, Selkoe DJ (1989) Relationship of microglia and astrocytes to amyloid deposits of Alzheimer disease. Neuroimmunology 24:173-182.

Iwamoto N, Nishiyama E, Ohwada J, Arai H (1994) Demonstration of CRP immunoreactivity in brains of Alzheimer's disease: immunohistochemical study using formic acid pretreatment of tissue sections. Neurosci Lett 177:23-26.

Jacob JS, Cistola DP, Hsu FF, Muzaffar S, Mueller DM, Hazen SL, Heinecke JW (1996) Human phagocytes employ the myeloperoxidase-hydrogen peroxide system to synthesize dityrosine, trityrosine, pulcherosine, and isodityrosine by a tyrosyl radical-dependent pathway. J Biol Chem 271:19950-19956.

Kaur H, Lyras L, Jenner P, Halliwell B (1998) Artefacts in HPLC detection of 3-nitrotyrosine in human brain tissue. $\mathrm{J}$ Neurochem 70:2220-2223

Keller JN, Kindy MS, Holtsberg FW, St. Clair DK, Yen HC, Germeyer A, Steiner SM, Bruce-Keller AJ, Hutchins JB, Mattson MP (1998) Mitochondrial manganese superoxide dismutase prevents neural apo- ptosis and reduces ischemic brain injury: suppression of peroxynitrite production, lipid peroxidation, and mitochondrial dysfunction. J Neurosci 18:687-697.

Kuiper MA, Visser JJ, Bergmans PL, Scheltens P, Wolters EC (1994) Decreased cerebrospinal fluid nitrate levels in Parkinson's disease, Alzheimer's disease, and multiple system atrophy patients. J Neurol Sci 121:46-49.

Li M, Sunamoto M, Ohnishi K, Ichimori Y (1996) $\beta$-Amyloid proteindependent nitric oxide production from microglial cells and neurotoxicity. Brain Res 720:93-100.

Lovell MA, Ehmann WD, Butler SM, Markesbery WR (1995) Elevated thiobarbituric acid-reactive substances and antioxidant enzyme activity in the brain in Alzheimer's disease. Neurology 45:1594-1601.

Lowry OH, Rosebrough NJ, Farr AL, Randall RJ (1951) Protein measurement with the folin phenol reagent. J Biol Chem 193:265-275.

Lukiw WJ, Bazan NG (1997) Cyclooxygenase 2 RNA message abundance, stability, and hypervariability in sporadic Alzheimer neocortex. J Neurosci Res 50:937-945.

Lyras L, Cairns NJ, Jenner A, Jenner P, Halliwell B (1997) An assessment of oxidative damage to proteins, lipids, and DNA in brain from patients with Alzheimer's disease. J Neurochem 68:2061-2069.

MacKenzie IRA, Hao C, Muñoz DG (1995) Role of microglia in senile plaque formation. Neurobiol Aging 16:797-804.

MacMillan-Crow LA, Crow JP, Thompson JA (1998) Peroxynitritemediated inactivation of manganese superoxide dismutase involves nitration and oxidation of critical tyrosine oxidation. Biochemistry 37:1613-1622.

Maesaka JJ, Wolf-Klein G, Piccione JM, Ma CM (1993) Hypouricemia, abnormal renal tubular urate transport, and plasma natriuretic factor(s) in patients with Alzheimer's disease. J Am Geriatr Soc 41:501-506.

Malencik DA, Anderson SR (1996) Dityrosine formation in calmodulin: cross-linking and polymerization catalyzed by Arthromyces peroxidase Biochemistry 35:4375-4386.

Malencik DA, Sprouse JF, Swanson CA, Anderson SR (1996) Dityrosine: preparation, isolation, and analysis. Anal Biochem 242:202-213.

Marquez LA, Dunford HB (1995) Kinetics of oxidation of tyrosine and dityrosine by myeloperoxidase compounds I and II. Implications for lipoprotein peroxidation studies. J Biol Chem 270:30434-30440.

Maruyama W, Hashizume Y, Matsubara K, Naoi M (1996) Identification of 3-nitro-L-tyrosine, a product of nitric oxide and superoxide, as an indicator of oxidative stress in the human brain. J Chromatogr B Biomed Appl 676:153-158.

Mattson MP, Goodman Y, Luo H, Fu W, Furukawa K (1997) Activation of NF 54B protects hippocampal neurons against oxidative stressinduced apoptosis: evidence for induction of manganese superoxide dismutase and suppression of peroxynitrite production and protein tyrosine nitration. J Neurosci Res 49:681-697.

McGeer PL, Itagaki S, Tago H, McGeer EG (1987) Reactive microglia in patients with senile dementia of the Alzheimer's type are positive for the histocompatibility glycoprotein HLA-DR. Neurosci Lett 79:195-200

McGeer PL, Akiyama H, Itagaki S, McGeer EG (1989) Activation of the classical complement pathway in brain tissue of Alzheimer patients. Neurosci Lett 107:341-346.

McKhann G, Drachman D, Folstein M, Khezman R, Price D, Stadlan EM (1984) Clinical diagnosis of Alzheimer's disease: report of the NINCDS-ADRDA work group under the auspices of Department of Health and Human Services task force on Alzheimer's disease. Neurology 34:939-944.

Mecocci P, MacGarvey U, Kaufman AE, Koontz D, Shoffner JM, Wallace DC, Beal MF (1993) Oxidative damage to mitochondrial DNA shows marked age-dependent increases in human brain. Ann Neurol 34:609-616.

Michon T, Chenu M, Kellershon N, Desmadril M, Gueguen J (1997) Horseradish peroxidase oxidation of tyrosine-containing peptides and their subsequent polymerization: a kinetic study. Biochemistry 36:8504-8513.

Milstien S, Sakai N, Brew BJ, Krieger C, Vickers JH, Saito K, Heyes MP (1994) Cerebrospinal fluid nitrite/nitrate levels in neurological diseases. J Neurochem 63:1178-1180.

Mirra SS, Hart MN, Terry RD (1993) Making the diagnosis of Alzheimer's disease. A primer for practicing pathologists. Arch Pathol Lab Med 117:132-144.

Mrak RE, Sheng JG, Griffin WST (1995) Glial cytokines in Alzheimer's disease: review and pathogenic implications. Hum Pathol 26:816-823. 
National Institute on Aging and Reagan Institute Working Group on diagnostic criteria for the neuropathological assessment of Alzheimer's disease (1997) Consensus recommendations for the postmortem diagnosis of Alzheimer's disease. Neurobiol Aging 18:S1-S2.

Navarro JA, Molina JA, Jimenez-Jimenez FJ, Benito-Leon J, Orti-Pareja M, Gasalla T, Cabrera-Valdivia F, Vargas C, de Bustos F, Arenas J (1996) Cerebrospinal fluid nitrate levels in patients with Alzheimer's disease. Acta Neurol Scand 94:411-414.

Oliver CN, Ahn BW, Moerman EJ, Boldstein S, Stadtman ER (1987) Age-related changes in oxidized protein. J Biol Chem 262:5488-5491.

Pearson RCA, Esiri MM, Hiorns RW, Wilcock GK, Powell TPS (1985) Anatomical correlates of the distribution of the pathological changes in the neocortex in Alzheimer disease. Proc Natl Acad Sci USA 82:4531-4534.

Pereira HA, Kumar P, Gramma P (1996) Expression of CAP37, a novel inflammatory mediator, in Alzheimer's disease. Neurobiol Aging 17:753-759.

Pfeiffer S, Gorren ACF, Schmidt K, Werner ER, Hansert B, Bohle DS, Mayer B (1997) Metabolic fate of peroxynitrite in aqueous solution. Reaction with nitric oxide and $\mathrm{pH}$-dependent decomposition to nitrite and oxygen in a 2:1 stoichiometry. J Biol Chem 272:3465-3470.

Price JL, Davis PB, Morris JC, White DL (1991) The distribution of tangles, plaques, and related immunohistochemical markers in healthy aging and Alzheimer's disease. Neurobiol Aging 12:295-312.

Rogers J, Webster S, Lue L-F, Brachova W, Civin WH, Emmerling M, Shivers B, Walker D, McGeer P (1996) Inflammation and Alzheimer's disease pathogenesis. Neurobiol Aging 17:681-686.

Salman-Tabcheh S, Rabgaoui N, Torreilles J (1993) Neutrophilcatalyzed dimerization of tyrosyl peptides. Free Radic Res Commun 19:217-227.

Savenkova MI, Mueller DM, Heinecke JW (1994) Tyrosyl radical generated by myeloperoxidase is a physiologic catalyst for the initiation of lipid peroxidation in low density lipoprotein. J Biol Chem 269:20394-20400.

Sayre LM, Zelasko DA, Harris PLR, Perry G, Salomon RG, Smith MA (1997) 4-Hydroxynonenal-derived advanced lipid peroxidation end products are increased in Alzheimer's disease. J Neurochem 68:2092-2097.

Schulz JB, Mathews RT, Jenkins BG, Ferrante RJ, Siwek D, Henshaw DR, Cipolloni PB, Mecocci P, Kowall NW, Rosen BR, Beal MF (1995) Blockade of neuronal nitric oxide synthase protects against excitotoxicity in vivo. J Neurosci 15:8419-8429.

Sheng JG, Ito K, Skinner RD, Mrak RE, Rovnaghi CR, van Eldik LJ, Griffin WST (1996) In vivo and in vitro evidence supporting a role for the inflammatory cytokine interleukin-1 as a driving force in Alzheimer pathogenesis. Neurobiol Aging 17:761-766.

Shigenaga MK, Blount HL, Christen S, Shigeno ET, Yip H, Ames B (1997) Inflammation and $\mathrm{NO}(\mathrm{X})$-induced nitration: assay for 3-nitrotyrosine by HPLC with electrochemical detection. Proc Natl Acad Sci USA 94:3211-3216.

Smith CD, Carney JM, Starke-Reed PE, Oliver CN, Stadtman ER, Floyd RA (1991) Excess brain protein oxidation and enzyme dysfunction in normal aging and in Alzheimer disease. Proc Natl Acad Sci USA 88:10540-10543.

Smith CD, Carney JM, Tatsumo T, Stadtman ER, Floyd RA, Markesbery WR (1992) Protein oxidation in aging brain. Ann NY Acad Sci 663:110-119.

Smith MA, Perry G, Richey PL, Sayre LM, Anderson VE, Beal MF, Kowall N (1996) Oxidative damage in Alzheimer's. Nature 382:120-121.

Smith MA, Harris PLR, Sayre LM, Beckman JS, Perry G (1997) Widespread peroxynitrite-mediated damage in Alzheimer's disease. J Neurosci 17:2653-2657.

Strauss S, Bauer J, Ganter U, Jonas U, Berger M, Volk B (1992) Detection of interleukin- 6 and $\alpha$-2-macroglobulin immunoreactivity in cortex and hippocampus of Alzheimer's disease patients. Lab Invest 66:223-230.

Su JH, Deng G, Cotman CW (1997) Neuronal DNA damage precedes tangle formation and is associated with up-regulation of nitrotyrosine in Alzheimer's disease brain. Brain Res 774:193-199.

Tohgi H, Abe T, Takahashi S, Kikuchi T (1993) The urate and xanthine concentration in the cerebrospinal fluid in patients with vascular dementia of the Binswanger type, Alzheimer type dementia, and Parkinson's Disease. J Neural Transm Park Dis Dement Sect 6: $119-126$.

Whiteman M, Halliwell B (1996) Protection against peroxynitritedependent tyrosine nitration and $\alpha 1$-antiproteinase inactivation by ascorbic acid. A comparison with other biological antioxidants. Free Radic Res Commun 25:275-283.

Wood JA, Wood PL, Ryan R, Graff-Radford NR, Pilapil C, Robitaille Y, Quirion R (1993) Cytokine indices in Alzheimer's temporal cortex: no changes in mature IL1- $\beta$ or IL-1RA but increases in the associated acute phase reactant proteins IL-6, $\alpha 2$-macro globulin, and c-reactive proteins. Brain Res 629:245-252.

Yi D, Smythe GA, Blount BC, Duncan MW (1997) Peroxynitritemediated nitration of peptides: characterization of the products by electrospray and combined gas chromatography-mass spectrometry. Arch Biochem Biophys 344:253-259. 